\title{
PEMBERDAYAAN EKONOMI KELUARGA PRASEJAHTERA MELALUI PEMANFATAAN SUMBER DAYA KELUARGA DAN LAHAN PEKARANGAN
}

Jurnal Pendidikan Luar Sekolah

http://kolokium.ppj.unp.ac.id/ Jurusan Pendidikan Luar Sekolah Fakultas Ilmu Pendidikan Universitas Negeri Padang Sumatera Barat, Indonesia

Volume 6, Nomor 2, Oktober 2018 DOI: 10.5281 /zenodo. 1471723

\author{
Tastil Bartin ${ }^{1,2}$, Irmawita', Wistoni ${ }^{1}$ \\ ${ }^{1}$ Jurusan Pendidikan Luar Sekolah Fakultas Ilmu Pendidikan Universitas Negeri Padang \\ ${ }^{2}$ Email: tasrilbartin@fip.unp.ac.id
}

\begin{abstract}
Community and family empowerment activities are classic activities that are currently still underestimated by many parties, but this is still relevant and urgent when linked to community service programs. This community service program is proven to have a direct impact on efforts to improve the quality of life of the community, especially for disadvantaged families or disadvantaged families. Through this paper, the authors raise several positive aspects that can be obtained from several stages of the implementation of community service conducted by Padang State University in Nagari Lubuk Jantan Tanah Datar Regency. The focus of the activity is the empowerment of pre-prosperous family economies through the utilization of family resources and yards. The election of Nagari Lubuk Jantan is based on the consideration that this area is relatively many target groups or communities that are still underdeveloped in various aspects of life, especially in the education aspects, social aspects, and cultural aspects, and low levels of welfare, while they have relatively large family members as well as large yards that are not used optimally. The results of these community service activities have a significant impact, including: increased public knowledge about family problems and potential, the community gets an understanding in increasing family income through the management of family resources, and skills in improving the family economy by choosing and cultivating plants of economic value in the yard around residential areas, especially for economically weak communities. It is expected that all parties, including universities, regional governments, the private world, and community leaders, can increase their awareness of the family empowerment program, especially in optimizing the utilization of the potential of family resources such as human resources, family assets and time. Therefore, in the future, a variety of scientific studies and a more comprehensive service program breakthrough and totality related to efforts to improve the quality of the family will lead to a more dignified prosperous family.
\end{abstract}

Keywords: Family Resources, Disadvantaged Families, Yard

\section{PENDAHULUAN}

Bangsa Indonesia yang besar dan kuat sangat mungkin diraih di masa datang apabila semua potensi besar yang dimiliki bangsa, yaitu penduduk, potensi sumber daya alam, potensi budaya, dan potensi keragaman nilai dapat dikelola dengan baik. Jika potensi penduduk yang besar ini dapat dikelola dengan baik maka hal ini disebut sebagai bonus 
Pemberdayaan Ekonomi Keluarga Prasejabtera Melalui Pemanfataan Sumber Daya...

demografi (demographic dividen). Sebaliknya jumlah penduduk yang besar dapat menjadi bencana demografi (demografic disaster) apabila tidak ditangani secara tepat. Mereka akan menjadi penganggur yang akan menjadi beban negara. Oleh sebab itu, usia produktif yang semakin tinggi ini bila dikembangkan melalui pendidikan yang tepat akan berkembang menjadi SDM handal yang dapat meningkatkan produktivitas dan kesejahteraan bangsa dan negara.

Dalam upaya peningkatan kesejahteraan masyarakat maka peran keluarga menjadi sangat penting. Keluarga menurut Undang-undang Nomor 52 Tahun 2009 adalah unit terkecil dalam masyarakat yang terdiri dari suami dan istri, ibu dan anaknya, atau ayah dan anaknya, atau ibu dan orang tuanya. Keluarga berkualitas adalah keluarga yang dibentuk berdasarkan perkawinan yang sah dan bercirikan sejahtera, sehat, maju, mandiri, memiliki jumlah anak yang ideal, berwawasan ke depan, bertanggung jawab, harmonis dan bertakwa kepada Tuhan Yang Maha Esa.

Sebenarnya banyak lembaga mitra yang bisa diajak untuk meningkatkan optimalisasi kegiatan pengabdian masyarakat oleh perguruan tinggi terutama pemerintah daerah dan pemerintah nagari, serta organisasi sosial kemasyarakatan lainnya. Namun, permasalahan klasik adalah terbatasnya anggaran pemerintah khususnya organisasi peerangkat daerah yang membidangi pemberdayaan masyarakat seperti dinas pendidikan, dinas pertanian, dinas sosial, dan OPD terkait lainnya. Selama ini program pendidikan nonformal dilaksanakan di daerah dekat dengan pusat pemerintahan saja, padahal banyak daerah lain atau nagari yang terisolir atau tertinggal yang perlu mendapat prioritas program terutama yang berorientasi pada peningkatan kualitas hidup dan peningkatan kesejahteraan masyarakat.

Beberapa parameter keberhasilan program pengabdian masyarakat oleh berbagai pihak adalah tergarapnya semua potensi sumber daya keluarga, pemanfaatan lingkungan atau lahan pekarangan yang maksimal, serta potensi sumber daya alam lainnya yang ada di sekitar mereka, sehingga mereka dapat hidup mandiri dan lebih sejahtera. Beberapa parameter di atas belum mendapat perhatian pemerintah setempat padahal relatif banyak kelompok sasaran yang sangat membutuhkan bimbingan dalam upaya meningkatkan taraf hidupnya. Umumnya keluarga prasejahtera tidak paham tentang potensi keluarga dan lingkungan mereka. Lahan pekarangan memiliki potensi dalam penyediaan bahan pangan keluarga, mengurangi pengeluaran rumah tangga untuk pembelian pangan dan meningkatkan pendapatan rumah tangga petani, namun mereka tidak mengetahui cara pemanfaatan lahan tidur untuk hal yang dapat meningkatkan pendapatan, padahal mereka mempunyai tenaga kerja dalam keluarga yang cukup untuk menggarap lahan tersebut sesuai dengan kemampuan masing-maing anggota keluarga.

Terkait dengan pengelolaan lahan pekarangan, terdapat beberapa kendala terkait dengan masalah sosial, budaya setempat, dan sistem ekonomi rumah tangga di pedesaaan, di antaranya adanya ketergantungan yang tinggi terhadap bantuan perantau untuk biaya hidup saudara yang di kampung, sehingga mereka kelihatan agak malas berusaha, belum nampak upaya pemanfaatan lahan tidur dengan budidaya tanaman pekarangan secara intensif, pemanfaatan lahan pekarangan masih bersifat sambilan dan belum berorientasi pasar, kurang pemahaman dan pengetahuan tentang pemanfaatan teknologi budidaya pertanian yang spesifik di lahan pekarangan. Di samping itu, proses pendampingan dari petugas dinas intansi terkait juga belum memadai. Oleh karena itu, diperlukan kerja sama yang matang dan bersifat lintas sektoral dalam pemanfaatan lahan pekarangan sehingga setiap keluarga lebih berperan dalam mendukung ketahanan pangan keluarga masing-masing. 
Melalui tulisan ini penulis mengangkat beberapa sisi positif yang bisa dipetik dari beberapa tahap pelaksanaan pengabdian masyarakat Universitas Negeri Padang di Nagari Lubuk Jantan Kabupaten Tanah Datar. Kegiatan yang menjadi fokus adalah pemberdayaan ekonomi keluarga prasejahtera melalui pemanfataan sumber daya keluarga dan lahan pekarangan. Alasan dipilihnya daerah ini adalah relatif banyaknya kelompok sasaran yang masih terbelakang dalam berbagai aspek kehidupan, khususnya pada aspek pendidikan, sosial, dan budaya, dan tingkat kesejahteraan. Di nagari ini juga ditemukan beberapa keluarga prasejahtera dengan jumlah anggota keluarga relatif banyak serta lahan pekarangan yang cukup luas, namun tidak dimanfaatkan secara optimal.

\section{ANALISIS SITUASI}

Beberapa permasalahan keluarga klasik adalah adalah: 1) masalah keuangan; 2) ketidakhadiran anak: 3) perselingkuhan; 4) kehidupan seksual; 5) istri kurang trampil dalam mengurus rumah tangga; 6) mertua ikut campur; 7) komunikasi; 8) perbedaan pandangan; 9) pendidikan. Ujung dari permasalahan ini adalah kekerasan dalam rumah tangga, perilaku menyimpang, bahkan terjadinya perceraian. Kasus perceraian merupakan kasus masalah terbesar yang berdampak material dan psikologis terhadap semua anggota keluarga. Byarwati (2011) mengemukakan bahwa pada tahun 2009, terdapat 250 ribu perkara perceraian. Jumlah tersebut sebanding beserta 10\% mengenai angka pernikahan di tahun 2009. Kebanyakan kasus perceraian $(70 \%)$ di pengadilan agama yaitu cerai gugat, di mana pihak istri yang menggugat cerai suaminya

Berdasarkan data kependudukan yang diperoleh dari Pemerintah Nagari Lubuk Jantan (2017) diketahui bahwa rata-rata tingkat kesejahteraan keluarga di daerah ini masih tergolong marjinal. Persolan-persoalan yang belum dapat teratasi sampai saat ini adalah tingkat pendidikan formal yang rendah, yaitu 10\% Buta Aksara atau tidak tamat SD, 40\% tamat SD, 30\% tamat SLTP, dan 20\% tamat SLTA. Masalah muncul dipermukaan adalah pengangguran, kemiskinan, pernikahan dini, keluarga broken home (kawin cerai), dan penyakit sosial lainnya. Kondisi ini berpotensi menimbulkan masalah sosial seperti gizi buruk balita, trafficking, kekerasan dalam rumah tangga, pelecehan seksual, dan berbagai kejahatan perempuan dan kejahatan kemanusiaan lainnya.

Permasalahan klasik pemerintah baik pada tingkat nasional, provinsi, kabupaten/ kota sampai ke nagari/kelurahan adalah terbatasnya anggaran dan sumber daya manusia dalam rangka meningkatkan kesejahteraan keluarga prasejahtera. Berbagai program yang berkaitan dengan peningkatan kesejahteraan masyarakat belum ditangani melalui proses dan pendekatan pendidikan masyarakat atau prinsip-prinsip pendidikan nonformal yang sebenarnya, di mana dalam pendidikan nonformal lebih mengedepankan pemberian pengetahuan, penyadaran, bimbingan dan advokasi, bukan hanya sekedar penerangan dan pemberian bantuan fisik semata.

Sebenarnya sudah banyak instansi atau organisasi perangkat daerah di tingkat kabupaten/kota yang bertanggung jawab dan bersentuhan langsung dengan layanan masyarakat, namun konsep yang ditawarkan belum menggunakan konsep pemberdayaan, baru sebatas tindakan kuaratif, yang lebih bersifat darurat dan belum ada pola perencanaan yang jelas dan berkelanjutan. 
Pemberdayaan Ekonomi Keluarga Prasejahtera Melalui Pemanfataan Sumber Daya...

Oleh karena terbatasnya anggaran dan sumber daya tadi maka sasaran serta wilayah program pendidikan nonformal cenderung dilaksanakan di daerah dekat dengan pusat pemerintahan, padahal wilayah yang terisolir dan tertinggal perlu diprioritaskan dengan program yang berorientasi peningkatan kualitas hidup dan peningkatan kesejahteraan masyarakat. Dengan demikian keberhasilan program akan dinilai dengan salah satu tolok ukurnya adalah tumbuhnya kemandirian masyarakat, dan tergarapnya semua potensi sumber daya keluarga, lahan pekarangan yang menganggur, serta potensi alam lainnya yang ada di sekitar mereka.

Tak jarang pemerintah setempat kurang peduli dengan kelompok sasaran yang sangat membutuhkan bimbingan dalam upaya meningkatkan taraf hidupnya. Sebagian keluarga tidak mengetahui cara pemanfaatan lahan tidur untuk hal yang menghasilkan, padahal mereka mempunyai tenaga kerja dalam keluarga yang cukup untuk menggarap lahan tersebut sesuai dengan kemampuan masing-maing anggota keluarga. Lahan pekarangan memiliki potensi dalam penyediaan bahan pangan keluarga, mengurangi pengeluaran rumah tangga untuk pembelian pangan dan meningkatkan pendapatan rumah tangga petani.

Sejumlah kendala terkait masalah sosial, budaya, dan ekonomi masih dijumpai dalam program pemanfaatan lahan pekarangan, di antaranya belum membudayanya budidaya pekarangan secara intensif, masih bersifat sambilan dan belum berorientasi pasar, kurang tersedianya teknologi budidaya spesifik pekarangan, serta proses pendampingan dari petugas yang belum memadai. Oleh karena itu, diperlukan perencanaan yang matang dan dukungan lintas sektoral dalam pemanfaatan lahan pekarangan sehingga mampu lebih optimal dalam mendukung ketahanan pangan. Sebagai contoh, berkebun adalah satu di antara kesibukan yang mengasyikkan dan juga menyehatkan sekaligus menghasilkan. Jika ada lahan pekarangan dan waktu senggang di rumah, keluarga dan anggotanya dapat memafaatkannya untuk berkebun dengan berbagai cara dan inovasi agar lahan anda menjadi produktif.

\section{KONSEP SUMBER DAYA KELUARGA}

Soelaiman (1994) meninjau dari sudut pedagogis bahwa keluarga merupakan satu persekutuan hidup yang dijalin kasih sayang antara pasangan dua jenis manusia dikukuhkan dengan pernikahan, yang bermaksud untuk saling menyempurnakan diri. Berns (1997) menyatakan bahwa keluarga memiliki fungsi ekonomi, sosial, fungsi pendidikan, fungsi dukungan, dan fungsi reproduktif. dari sekian fungsi yang diemban keluarga, fungsi pendidikan dan fungsi sosial menjadi lebih menonjol. Fungsi sosial dimaksudkan bahwa keluarga berkewajiban untuk membantu dan mempersiapkan anak menjadi anggota masyarakat. Dalam memerankan fungsi sosialisasi, kedudukan keluarga sebagai penghubung anak dengan kehidupan sosial dan norma-norma sosial.

Keluarga mempunyai peran penting dalam pendidikan karakter anak sejak usia dini untuk menumbuhkan sikap religius, nasionalis, mandiri, gotong royong, dan integritas, sebagai salah satu bentuk pengelolaan sumber daya manusia. Di dalam keluarga anak mengenal aturan-aturan sederhana maupun norma-norma kehidupan yang mengatur cara hidup bersama. Keluarga yang berhasil dalam melaksanakan fungsi sosial, sangat membantu anak dalam menemukan diri sebagai pribadi yang mantap sehingga mampu berpartisipasi dalam kehidupan masyarakat secara konstruktif. 
Sumber daya keluarga dapat dibagi atas 3 bagian yaitu: sumber daya manusia, sumber daya materi, dan sumber daya waktu. Oleh karena itu, mengelola sumber daya keluarga sangat penting untuk membantu setiap anggota keluarga dalam mengembangkan kerja sama dan saling membangun. Sumber daya keluarga merupakan modal yang harus dikelola dengan baik oleh seluruh anggota keluarga untuk mencapai kesejahteraan keluarga. Pembeda antara manusia yang berhasil dengan yang tidak, bukan terletak pada berapa banyak sumber daya yang dimilikinya, namun pada seberapa baik ia memanfaatkannya. Pembeda antara manusia yang berhasil dengan yang tidak, bukan terletak pada berapa banyak sumber daya yang dimilikinya, namun pada seberapa baik ia memanfaatkannya (Kemendikbud, 2016).

Kebutuhan setiap anggota keluarga sebenarnya tidak terbatas sedangkan sumber daya yang tersedia sangat terbatas. Hal ini merupakan hambatan dalam kehidupan keluarga. Salah satu faktor penyebab terjadinya permasalahan yang ada di dalam keluarga adalah tidak adanya pengelolaan sumber daya keluarga dengan baik. Apabila sebuah keluarga tidak dapat mengelola sumber dayanya dengan baik, maka keluarga tersebut akan sulit untuk mencapai tujuan yang diinginkan sehingga untuk membangun keluarga yang berkualitas pun akan sulit. Tidak adanya pengelolaan sumber daya keluarga yang baik juga dapat menyebabkan ketidakharmonisan dalam keluarga. Berbagai pertengkaran antara suami istri dan anak bisa terjadi karena kebutuhan-kebutuhan yang belum dapat terpenuhi sehingga pada akhirnya terjadi perceraian atau kehidupan keluarga yang berjalan tidak baik. Oleh karena itu, untuk mencapai kehidupan keluarga yang harmonis dan berkualitas, diperlukan adanya pengelolaan sumber daya keluarga dengan baik. Setiap anggota keluarga mempunyai tanggung jawab yang sama dalam mengelola sumber daya yang dimiliki, baik pada aspek tenaga kerja mapupun pada aspek aset atau lingkungan yang bisa dimanfaatkan.

Menurut Undang-Undang Nomor 10 Tahun 1992 Pasal 1 Ayat 10 menyebutkan pengertian keluarga berkualitas adalah keluarga yang dibentuk berdasarkan perkawinan yang sah dan bercirikan sejahtera, sehat, maju, mandiri, memiliki jumlah anak yang ideal, berwawasan ke depan, bertanggung jawab, harmonis dan bertakwa kepada Tuhan Yang Maha Esa. Sedangkan penduduk yang berkualitas dijelaskan pada ayat 5 yaitu kondisi penduduk dalam aspek fisik dan nonfisik yang meliputi derajat kesehatan, pendidikan, pekerjaan, produktivitas, tingkat sosial, ketahanan, kemandirian, kecerdasan, sebagai ukuran dasar untuk mengembangkan kemampuan dan menikmati kehidupan sebagai manusia yang bertakwa, berbudaya, berkepribadian, berkebangsaan dan hidup layak.

\section{KONSEP KESEJAHTERAAN KELUARGA}

Ferguson, Horwood \& Beutrais (Sumarwan \& Tahira, 1993) menyatakan bahwa kesejahteraan keluarga dapat dibedakan ke dalam kesejahteraan ekonomi (family economic well-being) dan kesejahteraan material (family material well-being). Kesejahteraan ekonomi keluarga, diukur dalam pemenuhan akan input keluarga (pendapatan, upah, aset dan pengeluaran), sementara kesejahteraan material diukur dari berbagai bentuk barang dan jasa yang diakses oleh keluarga.

Selain itu, konsep kesejahteraan dapat pula dikaitkan dengan konsep kebutuhan (needs), khususnya mengenai pemenuhannya. Maslow menggambarkan rumusan tentang kebutuhan yang hierarkis dalam bentuk segitiga, di mana kebutuhan yang ada di atas akan terpenuhi setelah kebutuhan di bawahnya terpenuhi. Tingkatan paling bawah dalam hierarkis kebutuhan tersebut adalah kebutuhan fisik yang menyangkut kebutuhan pokok seperti 
Pemberdayaan Ekonomi Keluarga Prasejabtera Melalui Pemanfataan Sumber Daya...

sandang, pangan dan papan. Kemudian berturut-turut adalah kebutuhan akan rasa aman, kebutuhan sosial dan kebutuhan penghargaan atas diri. Keterkaitan antara konsep kesejahteraan dan konsep kebutuhan adalah dengan terpenuhinya kebutuhan-kebutuhan tersebut, maka seseorang sudah dapat dinilai sejahtera. Karena tingkat kebutuhan tersebut secara tidak langsung sejalan dengan indikator kesejahteraan.Indikator Keluarga Sejahtera pada dasarnya mempunyai asumsi bahwa kesejahteraan merupakan variabel komposit yang terdiri dari berbagai indikator yang spesifik dan operasional. Karena indikator yang yang dipilih akan digunakan oleh kader di desa, yang pada umumnya tingkat pendidikannya relatif rendah, untuk mengukur derajat kesejahteraan para anggotanya dan sekaligus sebagai pegangan untuk melakukan melakukan intervensi, maka indikator tersebut selain harus memiliki validitas yang tinggi, juga dirancang sedemikian rupa, sehingga cukup sederhana dan secara operasional dapat di pahami dan dilakukan oleh masyarakat di desa.

Atas dasar pemikiran tersebut, Badan Koordinasi Keluarga Berencana Nasional (BKKBN) tahun 2004 menggunakan kriteria kesejahteraan keluarga untuk mengukur kemiskinan dan membaginya ke lima kelompok yaitu keluarga prasejahtera, keluarga sejahtera I, keluarga sejahtera II, keluarga sejahtera III, keluarga sejahtera III plus. Dari lima tingkatan tersebut yang perlu mendapat perhatian ekstra adalah keluarga prasejahtera yaitu keluarga yang belum dapat memenuhi kebutuhan dasarnya secara minimal, seperti kebutuhan akan pengajaran agama, pangan, sandang, papan dan kesehatan.

\section{KONSEP LAHAN PEKARANGAN}

Secara harfiah, pekarangan adalah sebidang tanah di sekitar rumah (bagian depan, samping maupun belakang) yang mudah di usahakan dengan tujuan untuk meningkatkan pemenuhan gizi mikro melalui perbaikan menu keluarga, dan biasanya dibatasi dengan pagar. Pekarangan dapat dikelola melalui pendekatan terpadu berbagai jenis tanaman, ternak dan ikan, sehingga akan menjamin ketersediaan bahan pangan yang beraneka ragam secara terus menerus, guna pemenuhan gizi keluarga. Namun dalam faktanya lahan pekarangan sering tidak termanfaatkan karena pemilik lahan atau keluarga yang menempati rumah tersebut menganggap bahwa pertanian merupakan mata pencaharian yang kurang menguntungkan dan juga pemilik lahan disibukkan dengan pekerjaan utama yang menyita waktu.

Jika kita amati lebih seksama, ternyata hampir semua rumah di desa atau nagari mempunyai lahan pekarangan yang dibiarkan tidur atau tidak produktif. Lahan tersebut dibiarkan kosong tak terurus atau tidak dimanfaatkan dengan berbagai inovasi yang menghasilkan. Umumnya pemilik lahan tidak mengetahui cara pemanfaatan lahan pekarangan untuk tanaman yang menghasilkan. Oleh karena itu, berkebun di pekarangan adalah satu di antara kesibukan yang mengasyikkan dan juga menyehatkan sekaligus menghasilkan uang. Jika ada waktu senggang di rumah, pemilik rumah dapat memanfaatkannya untuk berkebun dengan berbagai cara dan inovasi agar lahan anda menjadi produktif. Usaha di pekarangan jika dikelola secara intensif sesuai dengan potensi pekarangan, di samping dapat memenuhi kebutuhan konsumsi rumah tangga, juga dapat memberikan sumbangan pendapatan bagi keluarga.

Beberapa tanaman pekarangan yang bisa dijadikan komoditas untuk menghasilkan uang adalah tanaman jenis sayuran atau rempah, tanaman buah-buahan, dan tanaman hias. Teknis budidaya dapat dilakukan secara konvensional dengan memakai media tanah dan dapat juga dilakukan secara modern dengan sistem hidroponik. Pada tahap awal tentu akan 
lebih baik menggunakan sistem konvensional karena biayanya murah dan tidak memerlukan pengetahuan dan keterampilan khusus.

Lahan pekarangan sudah lama dikenal dan memiliki fungsi multiguna. Beberapa manfaat dari penggunaan lahan pekarangan adalah untuk menghasilkan: 1) bahan makan sebagai tambahan hasil sawah dan tegalnya; 2) sayur dan buah-buahan; 3) rempah, bumbubumbu dan wangi-wangian; 4) bahan kerajinan tangan; 5) obat keluarga; 6) unggas, ternak kecil dan ikan; serta 7) uang tunai.

Hasil pengabdian masyarakat oleh Dwiratna (2016) membuktikan bahwa kegiatan pengabdian ini dapat menambah pengetahuan warga tentang pentingnya pemanfaatan lahan pekarangan melalui penerapan konsep rumah pangan lestari untuk mendukung ketahanan pangan keluarga. Kondisi yang sama juga diharapkan akan terjadi pada peserta pengabdian di Nagari Lubuk Jantan.

\section{KEGIATAN PEMANFAATN LAHAN PEKARANGAN}

\section{Langkah-langkah}

\section{Sosialiasi}

Kegiatan sosialiasi dalam arti luas yaitu suatu proses interaksi dan juga proses pembelajaran seorang individu yang dimulai saat dia lahir sampai meninggal yang terkait dengan suatu proses dalam hidup seseorang untuk mempelajari berbagai macam kebiasaan seperti cara hidup, nilai-nilai dan norma-norma sosial yang terdapat dalam masyarakat dengan maksud supaya dapat diterima oleh masyarakat. Dengan proses ini seseorang dapat mengadopsi kebiasaan, sikap maupun ide orang lain sehingga dapat dipercaya dan diakui. Dalam arti sempit sosialisasi adalah proses pembelajaran yang dilakukan seseorang untuk mengenal lingkungan sekitarnya baik itu lingkungan fisik maupun sosial. Pengenalan lingkungan dilakukan seorang individu untuk menyesuaikan dirinya dengan lingkungan, yang nantinya akan membekali dirinya di dalam pergaulan yang luas.

Sosialisasi bertujuan supaya seorang individu dapat mengenal, mengakui dan menyesuaikan dirinya dengan nilai, norma dan struktur sosial yang terdapat dalam masyarakat. Melalui sosialsiasi juga dapat dilakukan penyebarluasan dan mewariskan nilai, norma serta kepercayaan yang terdapat di dalam masyarakat. Sehingga nilai-nilai, normanorma dan kepercayaan tersebut dapat terpelihara oleh semua anggota masyarakat.

Tujuan akhir dari pelaksanaan sosialisasi adalah agar masyarakat bertambah pengetahuannya tentang suatu pokok persoalan yang dipaparkan, baik persoalan terkait dengan diri dan keluarganya sendiri maupun persoalan terkait dengan lingkungannya. Dalam kegiatan sosialisasi pada program pengabdian ini masyarakat diberi pengetahuan tentang beberapa hal di antaranya: 1) Masalah-masalah seputar manajemen keluarga; 2) Potensi ekonomi keluarga; 3) Perubahan perilaku ke arah inovasi usaha keluarga; 4) Teknik budidaya berbagai tanaman di lingkungan pekarangan; 5) Pemasaran dan kerja sama kelompok dalam usaha bididaya tanaman pekarangan.

Melalui kegiatan ceramah, diskusi, demonstrasi, serta praktek usaha budidaya tanaman secara langsung, kelompok sasaran pengabdian mendapatkan perubahan perilaku 
Pemberdayaan Ekonomi Keluarga Prasejabtera Melalui Pemanfataan Sumber Daya...

bagaimana meningkatkan pendapatan keluarga prasejahtera melalui peningkatan potensi lahan di sekitar rumah masing-masing.

\section{Workshop}

Workshop adalah frasa kata dari bahasa Inggris yaitu work dan shop (yang memiliki arti kerja dan toko). Secara harfiah workshop dapat diartikan sebagai tempat berkumpulnya para pelaku aktivitas (berkaitan dengan bidang dunia kerja) tertentu di mana para pelakunya melakukan interaksi saling menjual gagasan yang ditujukan untuk memecahkan suatu permasalahan tertentu.

Beberapa langkah yang dilakukan dalam kegiatan worksop pemanfaatan lahan pekarangan ini adalah sebagai berikut: 1) Penjelasan tujuan pelaksanaan kegiatan workshop pemanfaatan lahan yang ingin dicapai dalam kurun waktu tertentu, salah satunya adalah bagaimana meningkatkan kualitas keluarga yaitu berpindah dari keluarga prasejahtera kepada keluarga sejahtera I atau yang lebih tinggi; 2) Perumusan berbagai macam masalah pokok yang ingin dibahas dalam acara workshop ini di antaranya, pengaturan fungsi anggota keluarga, perubahan cara hidup anggota keluarga, serta peningkatan pendapatan keluarga. Kegiatan ini dilakukan dengan menganalisis sendiri masalah-maslah keluarga, dan peluang usaha peningkatan ekonomi keluarga; 3) Tentukan prosedur teknis pemecahan masalah yang akan digunakan misalnya diskusi, demonstrasi, atau praktik usaha pertanian.

\section{Bimbingan dan Penyuluhan}

Bimbingan adalah suatu usaha bantuan yang dilakukan oleh seseorang yang mempunyai keahlian dan pengalaman dalam memberikan bantuan atau pertolongan kepada individu tersebut dapat mengembangkan potensi yang dimiliki, mengenal dirinya dan dapat bertanggung jawab. Sedangkan penyuluhan adalah bantuan yang diberikan individu dalam memecahkan masalah kehidupannya dengan langsung berhadapan muka, dengan cara-cara yang sesuai dengan keadaan individu yang dihadapi untuk mencapai kesejahteraan hidupnya. Bimbingan dan penyuluhan ada persamaannya dan ada perbedaannya. Persamaan adalah keduanya merupakan suatu bantua bagi individu-individu dalam menghadapi problem kedupannya. Sedangkan perbedaan, bimbingan lebih luas dari pada penyuluhan, bimbingan lebih menitikberatkan pada segi-segi preventif, sedangkan penyuluhan lebih menitikberatkan pada segi kuratif.

Pada kegiatan ini beberapa langkah kegiatan yang dilakukan adalah: 1) Penentuan bentuk penyuluhan dan subjek penyuluhan. Bentuk penyuluhan yang dilaksanakan adalah workshop peningkatan kualitas keluarga dan ekonomi keluarga; 2) Menentukan metode yang digunakan. Dalam hal ini metode yang digunakan adalah ceramah, diskusi, demonstrasi, praktek kerja; 3) Pendekatan yang digunakan. Dalam hal ini pendekatan dimulai secara berkelompok kemudian diteruskan secara individu dari rumah ke rumah; 4) Media yang digunakan. Dalam hal ini bimbingan dan penyuluhan menggunakan media belajar bukubuku, gambar, video, dan media tanam, serta bahan-bahan lain yang diperlukan untuk praktek bididaya tanaman pekarangan; 5) Proses pelaksanaan, yaitu dengan memberikan teori dilanjutkan dengan praktik sekali seminggu pada tahap awal dan sekali sebulan pada tahap berikutnya. 


\section{Pemantauan dan Pendampingan}

Pemantauan atau monitoring merupakan suatu kegiatan yang dilakukan dengan cara menggali untuk mendapatkan informasi secara regular berdasarkan indikator tertentu, dengan maksud mengetahui apakah kegiatan yang sedang berlangsung sesuai dengan perencanaan dan prosedur yang telah ditetapkan. Kegiatan pemantauan ini dilakukan minimal sekali 1 bulan sejak dilaksanakan sosialisasi, workshop/praktik, dan implementasi kegiatan. Pemantauan dapat dilakukan secara bersama dengan pihak terkait seperti pelaksana kegiatan, narasumber dan tokoh masyarakat. Temuan pemantauan ini dikaji dan dianalisis untuk dilakukan penyesuaian-penyesuaian seperlunya sesuai dengan tujuan dan langkah-langkah kegiatan yang sudah ditetapkan.

Dalam kegiatan ini beberapa aspek yang perlu dipantau adalah: 1) Semangat, keseriusan, dan respon anggota kelompok untuk merubah perilaku ke arah yang lebih baik; 2) Terjadinya proses pertumbuhan tanaman pekarangan ke arah yang lebih baik; 3) Berkembangnya luas pemanfaatan lahan melebihi luas lahan yang digarap sebelumnya; 4) Panen dan pasca panen yang lebih bernilai ekonomi; 5) Bertambahnya pendapatan keluarga untuk mencapai keluarga yang lebih sejahtera; 6) Masalah dan hambatan pelaksanaan kegiatan.

\section{Evaluasi dan Tindak Lanjut}

Setelah hasil monitoring diperoleh maka dilakukan evaluasi program agar diperoleh umpan balik program yang memerlukan perbaikan, kebutuhan peserta program yang belum terlayani, kemampuan tim dalam melaksanakan program, serta dampak program terhadap perubahan perilaku peserta kegiatan dan pencapaian hasil kegiatan, peningkatan mutu proses pembelajaran dan peningkatan mutu kegiatan secara umum.

Hasil monitoring dan analisa harus ditindaklanjuti dengan menyusun program selanjutnya sebagai kesinambungan program, mengembangkan jejaring pelayanan agar pelayanan bimbingan dan konseling lebih optimal, melakukan referal bagi peserta program yang memerlukan bantuan khusus dari ahli lain, serta mengembangkan komitmen baru kebijakan orientasi dan implementasi pelayanan bimbingan dan koseling selanjutnya.

Beberapa hal yang perlu ditindaklanjuti dari program ini adalah: 1) Kesinambungan program pada tahun berikutnya dengan skala yang lebih luas melalui pembenahan dalam aspek sasaran, metode, waktu, dan peran antar instansi. Program kerja sama antar instansi terkait sangat dimungkinkan, baik dari perguruan tinggi, dinas pemerintah daerah, swasta, dan tokoh masyarakat; 2) Diseminasi. Kegiatan ini menjadi penting dalam rangka memperluas dampak kegiatan kepada kelompok masyarakat lain yang mempunyai permasalahan yang sama. Diseminasi dapat dilakukan oleh dinas dan instansi lain lewat program kunjungan, pelatihan, dan penyebaran informasi melalui media masa.

Penyediaan anggaran yang cukup oleh dinas/instansi terkait yang peduli dengan peningkatan kualitas keluarga prasejahtera, peningkatan ekonomi keluarga, dan kesejahteraan masyarakat pada umumnya. pembiayaan Pembiayaannya dapat dimasukkan ke dalam anggaran pemerintah daerah/nagari/desa, CSR perusahaan, dan sumbangan perantau dan tokoh masyarakat lainnya. 
Pemberdayaan Ekonomi Keluarga Prasejabtera Melalui Pemanfataan Sumber Daya...

\section{KESIMPULAN DAN SARAN}

\section{Kesimpulan}

Berdasarkan uraian di atas dapat ditarik beberapa kesimpulan, antara lain:

1) Kegiatan pemberdayaan masyarakat merupakan kegiatan klasik yang saat ini masih dipandang enteng oleh banyak pihak, namun kegiatan ini dipandang urgen karena memberikan dampak yang cukup siginifikan dalam upaya peningkatan kualitas kehidupan masyarakat.

2) Keluarga merupakan salah satu aspek penting dan merupakan objek pembangunan dewasa ini yang perlu mendapatkan perhatian lebih. Oleh karena itu, melalui pendidikan keluarga, berbagai masalah keluarga dapat terpecahkan dan berbagai potensi sumber daya keluarga dapat dikembangkan secara baik untuk peningkatan ekonomi keluarga prasejahtera

3) Salah satu upaya yang paling efektif dan efisien dalam rangka memenuhi kebutuhan pangan serta meningkatkan pendapatan keluarga adalah melalui pemanfaatan lahan pekarangan dengan budidaya tanaman yang bernilai ekonomi.

\section{Saran} berikut:

Adapun beberapa saran yang dapat diberikan kepada pihak terkait adalah sebagai

1) Diharapkan kepada semuam pihak baik perguruan tinggi, pemerintah daerah, dunia swasta, dan tokoh masyarakat meningkatkan kepeduliannya pada program pemberdayaan keluarga, khususnya upaya pemanfaatan potensi sumber daya keluarga seperti SDM, aset, dan waktu.

2) Diperlukan berbagai kajian ilmiah dan terobosan program pengabdian yang lebih komprehensif dan totalitas terkait dengan upaya peningkatan kualitas keluarga menuju keluarga sejahtera yang lebih bermartabat.

\section{DAFTAR RUJUKAN}

Berns, R. (1997). Child, Family, School, Community: Socialization and Support. Boston: Allyn and Bacon.

BKKBN. (2004). Kriteria Kesejabteraan Keluarga. Jakarta: BKKBN.

BKKBN. (2004). Undang-undang Nomor 52 Tabun 2009 tentang Perkembangan Kependudukan dan Pembangunan Keluarga. Jakarta: BKKBN.

Byarwati, A. (2011). Tatanan Berkeluarga dalam Islam. Jakarta: Lembaga Kajian Ketahanan Keluarga Indonesia.

Dwiratna, N.P, Widyasanti, A., Rahmah DM. (2016). Pemanfaatan Lahan Pekarangan Dengan Menerapkan Konsep Kawasan Rumah Pangan Lestari. Jumal Aplikasi Iptek untuk. Masyarakat 5 (1), Mei 2016, 19-22.

Kemendikbud. (2016). Mengelola Sumber daya Keluarga: Buku Seri Pendidikan Orang Tua. Jakarta: Kemendikbud. 
Pemerintahan Nagari Lubuk Jantan. (2017). Data Demografi Nagari Lubuk Jantan Tabun 2017. Batusangkar: Nagari Lubuk Jantan.

Soelaiman. (1994). Pendidikan Karakter, Solusi yang Tepat untuk Membangun Bangsa. Bogor: Indonesia Heritage Fondation. 